Ann. Biol. anim. Bioch. Biophys., 1977, 17 (3 A), 393-397.

\title{
In vitro macromolecular transfer between calf and macaque graafian follicles and culture media.
}

\author{
par Y. MENEZO, Micheline GERARD * \\ avec la collaboration technique de $M^{\text {me }}$ CHAQUÉ KHATCHADOURIAN \\ Laboratoire de Biologie animale, I.N.S.A., \\ 20, avenue Albert-Einstein 69621 Villeurbanne, France. \\ * Station de Physiologie animale, I.N.R.A., \\ 78350 Jouy-en-josas, France.
}

It has been suggested that growing (or atretic) follicles play a role in the regulation of ovarian follicle populations (Peters, 1973). However, no information is available on the release of macromolecules from the follicular fluid into the surrounding vessels or tissues. In vitro culture seems to be a valuable technique for such a study.

\section{Material and methods.}

Calf and macaque follicles were collected using our routine technique (Thibault ef al., 1975a, 1976). They were cultured either on grid (Thibault ef al., 1975b) or employing a continuous gas medium flow cell method (Ménézo ef al., 1976). The gas phase was 57 p. $100 \mathrm{O}_{2}, 5$ p. $100 \mathrm{CO}_{2}, 38$ p. $100 \mathrm{~N}_{2}$ and the culture medium entirely synthetic (medium B, Ménézo, 1976). We did some medium trials, replacing BSA (1 p. 100) by 1.2 .5 p. 100 of Ficoll 70 (Pharmacia) (medium C).

$0.5 \mathrm{IU} / \mathrm{ml}$ of PMS was added during the first 24 hours of culture and $0.5 \mathrm{IU} / \mathrm{ml}$ of PMS and $5 \mathrm{lU} / \mathrm{ml}$ of HCG during the following 26 hours. The medium was then recovered for analysis, and the follicles fixed for histological examination to determine oocyte nuclear stages and if pyknosis was present in the granulosa and cumulus cells.

\section{Electrophoresis.}

$5 \mu \mathrm{l}$ samples of follicular fluid were chemically analyzed before culture; the medium underwent the same analysis after $50 \mathrm{hrs}$ of culture. We used PAA 4/30, Pharmacia system with acrylamide gradient gels in tris-glycine buffer ( $\mathrm{pH} 8.3)$, which permitted separation according to molecular weight. The migration time was $18 \mathrm{hrs}$ at $110 \mathrm{~V}\left(4^{\circ} \mathrm{C}\right)$; staining was done with 0.1 p. 100 amido black in 7 p. 100 acetic acid.

Two types of medium were tested :

- media from the culture of macaque or bovine follicles which were still healthy at the end of culture. Oocytes in these follicles reached metaphase I or metaphase II ; 
- media from three calf follicles, presumably healthy at the beginning of culture, but with large pyknotic granulosa areas after culture.

\section{Enzymes.}

Hydrolytic enzymes were detected semi-quantitatively by colorimetric method with naphtol salts (Monget, 1975) ; dehydrogenases were tested according to Altmann (1969).

\section{Results.}

\section{Electrophoresis.}

BSA monomer and dimer are the only macromolecules of control medium B.

Eighteen bands were detected in calf follicular fluid and 15 bands in macaque follicular fluid. Heavy molecular-weight proteins were weakly represented, confirming the results of Shalgi ef al. (1973) (fig 1).

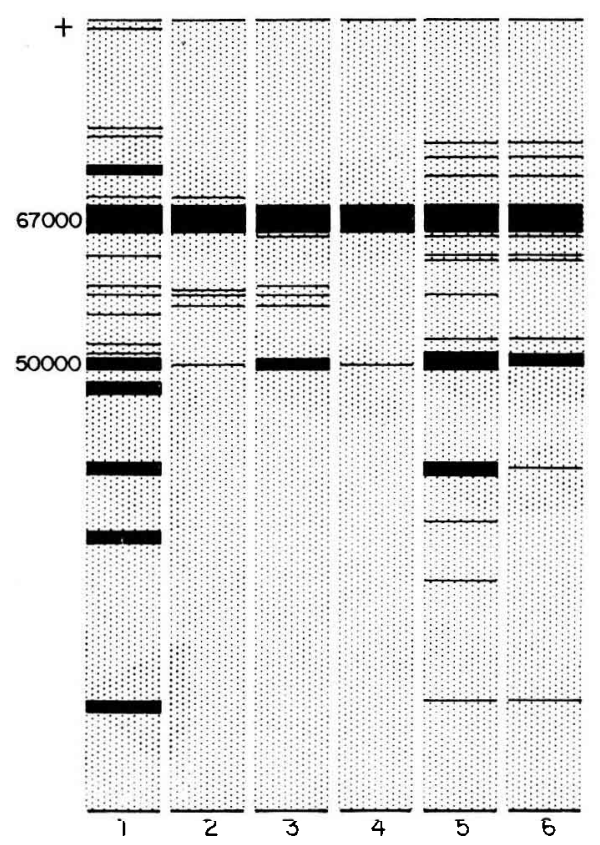

FIG. 1. - Acrylamid gel electrophoresis of follicular fluid.

1 : Calf follicular fluid ; 2 : Medium (with BSA) after 50 hrs of calf follicle culture (meiosis reaches $M I) ; 3$ : Medium with Ficoll after $50 \mathrm{hrs}$ of calf follicle culture (meiosis resumes up to $M \mathrm{II}$ ) ; 4 : Control medium (with BSA) or medium after culture of an atretic calf follicle ; 5 : Macaque follicular fluid before culture ; 6 : Medium after a 50 hrs-culture of a macaque follicle (meiosis stage : $M I)$.

67,000 : BSA ; 150,000 : BSA dimer. 
When follicles remained healthy during all the culture, some proteins migrated from the follicular fluid into the medium. With calf follicles (12 experiments) we found mainly proteins with molecular weight between 80,000 and 100,000 , although proteins of lower molecular weight $(50,000)$ were also present. The medium had a broader molecular profile $(40,000-220,000)$ in the macaque (6 trials). Due to method sensitivity, molecules lower than 40,000 were not detected in the medium, although they were undoubtedly present.

Culture media of atretic follicles do not show any difference with the control medium, indicating that permeability of atretic follicles was completely impaired. However, results are rather heterogeneous in both species. The number of proteins transferred from the follicle to the medium varies and has no correlation with the nuclear maturation stage reached (metaphase I or metaphase II).

Medium $C$ with no protein shows that follicular BSA also migrates from healthy follicles into the medium during culture. Both BSA monomer and dimer are found, but we do not know if dimerization occurs in the medium.

\section{Enzyme activity.}

$\beta$ glucuronidase and isocitrate dehydrogenase were detected in calf follicular fluid before culture and were not found in the medium. This observation concords with the molecular weight of these proteins, and the possibility that macromolecules traverse the follicle wall as previously shown; $\beta$ glucuronidase molecular weight is higher than 210,000 and that of isocitrate dehydrogenase about 300,000 .

TABLE 1

Enzymes found in control follicular fluid and in the culture medium offer 50 hrs culture (calf)

\begin{tabular}{|c|c|c|}
\hline . & $\begin{array}{l}\text { Before culture } \\
\text { (follicular fluid) }\end{array}$ & $\begin{array}{c}\text { After culture } \\
\text { (medium) }\end{array}$ \\
\hline 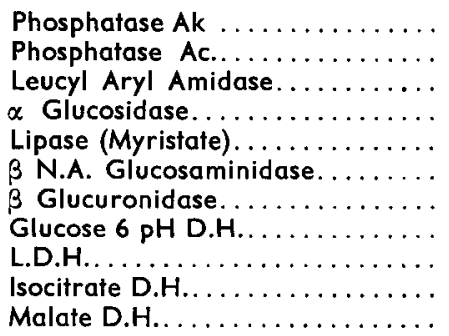 & $\begin{array}{l}+(1) \\
+(1) \\
+ \\
+ \\
0 \\
+ \\
+ \\
+(1) \\
+(1) \\
+(1)\end{array}$ & $\begin{array}{l}+ \\
+ \\
+ \\
+ \\
+ \\
+ \\
0 \\
+ \\
+ \\
0 \\
+\end{array}$ \\
\hline
\end{tabular}

(1) Already mentioned by Kenney, 1973.

Two enzymes, lipase (M. W. 40,000-60,000) and malate dehydrogenase ( $M$. W. $\# 60,000$ ), not detectable in the follicular fluid at zero time, were present in the medium at the end of culture. As shown by Dekel ef al. (1976), it is suggested that the presence 
of malate dehydrogenase is related to the change towards aerobic pathways induced by HCG.

\title{
Conclusion.
}

Macromolecules traverse follicle membranes only if follicles remain healthy during culture. When granulosa is pyknotic at the end of culture, migration is completely abolished. In healthy follicles, macromolecule migration seems to be molecularweight dependent. Molecules heavier than 150,000 in calf and 220,000 in macaque remain in the follicular fluid. These observations indicate that atretic follicles in vivo do not play any role in intra- or extraovarian regulation of folliculogenesis. The release of enzymes into the medium may furnish an indication of the metabolic changes induced by gonadotropins.

\author{
Accepté en janvier 1977.
}

Résumé. La culture de follicules à antrum dans un milieu synthétique contenant soit de la BSA, soit du Ficoll permet d'étudier leur perméabilité aux macromolécules présentes dans le liquide folliculaire.

Quand le follicule demeure sain durant la culture, on retrouve, dans le milieu, après $48 \mathrm{~h}$, des macromolécules jusqu'à un poids moléculaire de 150000 pour le veau et de 220000 pour le macaque. Parmi les molécules retrouvées, figurent deux enzymes, une lipase et le malate déshydrogénase dont la synthèse a été induite in vitro par les gonadotropines.

Les follicules qui deviennent atrétiques ne libèrent aucune macromolécule, ce qui indique que l'atrésie entraîne une suppression de la perméabilité et qu'en conséquence in vivo les follicules atrétiques ne peuvent probablement pas participer aux régulations du fonctionnement des divers compartiments ovariens, tout au moins par des molécules dans la limite des poids moléculaires étudiés.

\section{References}

ALTMANN F. P., 1969. The use of eight different tetrazolium salts for the quantitative study of pentose shunt dehydrogenation. Histochemie, 19, 363-374.

DEKEL N., HULTBORN R., HILLENSJO T., HAMBERGER L., HAMBERGER L., KRAICER P., 1976. Effect of luteinizing hormone on respiration of the preovulatory cumulus oophorus of the rat. Endocrinology, 98, 498-504.

KENNEY R. M., 1973. Histoenzymologic evaluation of metabolic patterns in bovine follicular oocytes. Am. J. vet. Res., 34, 893-896.

MÉNÉZO Y., 1976. Milieu synthétique pour la survie et la maturation des gamètes et pour la culture de l'œuf fécondé. C. R. Acad. Sci. Paris, série D, 282, 1967-1970.

MÉNÉZO Y., GÉRARD M., THIBAULT C., 1976. Culture du follicule de de Graaf de bovin dans un système à courant liquide et gazeux continu. C. R., Acad. Sci., Paris, série $D, 283,1309-1311$.

MONGET D., 1975. Différences d'activités enzymatiques entre deux lignées cellulaires d'insectes Antherea eucalypti et Malacosoma disstria (Lepidoptera). C. R. Acad. Sci., Paris série D, 281, 651654.

PETERS H., 1973. Development and atresia of follicles in the immature mouse. Coll. sur l'Ovogenèse et la folliculogenèse. Ann. Biol. anim. Bioch. Biophys., 13, hors série, 167-175.

SHALGI R., KRAICER P., RIMON A., PINTO M., SOFERMAN N., 1973. Proteins of human follicular fluid : the blood follicle barrier. Fertil. Steril., 24, 429-434. 
THIBAULT C., GÉRARD M., MÉNÉZO Y., 1975a. Preovulatory and ovulatory mechan isms in oocyte maturation. J. Reprod. Fert., 45, 605-610.

THIBAULT C., GÉRARD M., MÉNÉZO Y., 1975b. Acquisition par l'ovocyłe de lapine et de veau du facteur de décondensation du noyau du spermatozoïde fécondant (MPGF). Ann. Biol. anim. Bioch. Biophys., 15, 705-714.

THIBAULT C., GÉRARD M., MÉNÉZO Y., 1976. Nuclear and cytoplasmic aspects of mammalian oocyle maturation in vitro in relation to follicle size and fertilization. In P. O. HUBINONT, M. L'HERMITE, J. SCHWERS, «Sperm Action », Progr. Reprod. Biol., 233-240, Karger, Basel. 